\title{
PENGARUH PENDAPATAN ASLI DAERAH, DANA ALOKASI UMUM DAN DANA OTONOMI KHUSUS TERHADAP TINGKAT KEMISKINAN DI PROVINSI ACEH PERIODE 2010-2017
}

\author{
Muhammad Kadafi ${ }^{* a}$ Murtala $^{*}$, \\ *Fakultas Ekonomi dan Bisnis Universitas Malikussaleh \\ a Corresponding author : muhammadkadafi.se@gmail.com \\ bmurtala@unimal.ac.id
}

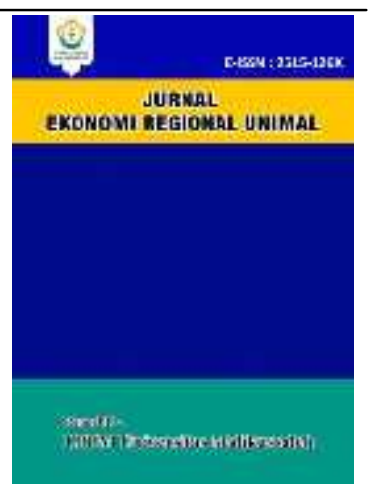

\section{A R T I CLE IN F ORMA TION A B S T RA C T}

Keywords:

Local Revenue, General Allocation Fund, Special Autonomy Fund, Poverty Rate
This study aims to analyze the Effect of Local original Revenue, General Allocation Funds and Special Autonomy Funds on Poverty Rates in Aceh Province 2010-2017. The data used in this study are panel data from 2010 to 2017. This research model uses panel data regression. Results of the study Partially the local original revenue and the special autonomy fund did not affect poverty in the Aceh Provincial Government, the general allocation fund affected the poverty in the Aceh Provincial Government. Simultaneously, local original revenue, general allocation funds and special autonomy funds affect poverty in the Aceh Provincial Government.

\section{PENDAHULUAN}

Secaraumum angkat masyarakat hidup dibawah tekanan Kemiskinandi Indonesia pada Tahun 2019 sudah terjadipenurunan.Penurunan jumlah penduduk kurang mampu/miskin tercapai 810.000 penduduk apabila diperbandingkan dengan angka penduduk dibawah tekanan Keniskinanpada tahun 2018. Jika dipantau pada persentase, jumlah penduduk yang miskin sampai bulan Maret tahun 2019 mencapai 9,41\% atau turunapabila diperbandingkan dengan tahun sebelumnya yang mencapai $9,82 \%$. Badan Pusat Statistik, (2019) melansir peringkat provinsi untuk tujuan Keniskinanter unggul di Sumatera.

Hasilnya, Aceh, yang mempunyai kekayaan alam besar dan dana alokasi khusus, malah menempati Rangking ter unggul kemiskinannya. angka penduduk miskin terbanyakyaitu di Provinsi Aceh, dinyatakan sebagai sebesar 15,68 persen. Badan Pusat Statistik (BPS) Aceh menyebutkan bahwa jumlah orang miskin di provinsi Aceh bertambah sebanyak 10.000 jiwa pada Maret 2018, kalau dibandingkan September 2017, Pada Tahun 2018 Pendudukmiskin di Aceh tercapai 839 riibu orang atau $15,97 \%$. Sementara pada bulan September tahun 2017 terdapat 829.000 orang.

Salah satu ciri pertama suatu daerahmampu melakukan otonomi suatu daerahdinyatakan sebagai pada kemampuan keuangan suatu daerahuntuk membiayai penyelenggaraan pemerintah daerahnya untuk tujuan tingkat angka proporsi ketergantungan pada pemerintah pusat yang semakin kecil dan diharapkan bahwa pemdapatan asli suatu daerahharus menjadi alat utama dalam dana pembangunan ekonomi daerah. Tujuan dari otonomi suatu daerahdinyatakan sebagai untuk menekan angka Keniskinandalam suatu daerah.

Adanya otonomi suatu daerahmemberikan kewenangan kepada masing masing suatu daerahuntuk mampu mengelola suatu daerahuntuk tujuan lebih luas. Pemerintah suatu daerahdi harapkan mampu menggali sumber-penghasilan pemdapatan asli suatu daerahsehingga akan meningkatkan tingkat angka kemandiriannya terhadap pusat. Pemdapatan Asli Suatu daerahyang mempunyai tingkat angka pertumbuhan PAD yang positif mempunyai kemungkinan untuk mempunyai pertumbuhan ekonomi yang lebih baik, yang salah satu indikatornya terjadi penurunan kemiskinan. Sesuai untuk tujuan hasil penelitian Siregar (2007) bahwa pertumbuhan ekonomi berpengaruh signifikan terhadap penurunan kemiskinan. PAD menunjukkan salah satu penghasilan belanja daerah, Abbdullah dan Hallim (2004) menemukan bahwa penghasilan pemdapatan suatu daerahberupa PAD berpengaruh terhadap belanja suatu daerahsecara keseluruhan.

Jadi untuk tujuan bertambahnya penghasilan 
pemdapatan suatu daerahdari PAD akan lebih membantu suatu daerahdalam melaksanakan anggaran yangmemihak kepada penduduk miskin (propoor budgeting).

Selain pemdapatan asli daerah, dalam rangka untuk menekan tingkat angka Kemiskinanpemerintah juga memberikan dana alokasi umum. Dana Alokasi umum menunjukkan sejumlah dana yang diberikan Pemerintah Pusat kepada setiap Suatu daerahOtonomi (Provinsi/Kabupaten/Kota) di Indonesia setiap tahunnya sebagai dana pembangunan. Sedangkan belanja Pemerintah Provinsi Aceh dialokasikan terbanyak kepada belanja barang dan jassa untuk tujuan menghasilkan sebesar $28-50 \%$ setiap tahunnya.(Bps,2018). Penghasilan pemdapatan tertinggi berasal dari dana perimbangan, terutama dari DAU dan DAK untuk tujuan kontribusi sebesar $58-80 \%$ per tahun.

Dana PAD sangat kecil jumlahnya. Sedangkan belanja seluruh tingkat angka dua dalam Provinsi Aceh berjumlah 15,5 - 30,9 trilyun rupiah pada tahun 2013 - 2017. Sebagian besar belanja ini untuk belanja pegawai, dinyatakan sebagai sejumlah 37 - 58 persen/tahun. (Bps,2018) Secara total, pemdapatan suatu daerahAceh yang berpenghasilan dari dana Provinsi Aceh dan seluruh dana Kabupaten/Kota terus naik setiap tahun.

Untuk belanja suatu daerahAceh, sebagian besar dialokasikan untuk belanja pegawai.(Bps,2018) Otonomi suatu daerahberlaku secara umum di Indonesia kecuali Papua, Papua Barat, dan Aceh yang diberlakukan otonomi khusus atau dapat dikategorikan sebagai desentralisasi asimetris (asymmetrical decentralization).

Desentralisasi ini menunjukkan berlakunya kewenangan khusus pada wilayah-wilayah tertentu dalam suatu negara, yang dianggap sebagai alternatif untuk menuntaskan berbagai permasalahan hubungan pusat dan daerah. Terkait untuk tujuan permasalahan di Aceh, Pemerintah sudah merespon untuk tujuan berlakunya UndangUndang Nomor 11 Tahun 2006 Tentang Pemerintah Aceh dimana menyatakan bahwa beberapa hal yang mendasari pertimbangan diberlakukannya otonomi khusus bagi Provinsi Aceh, dinyatakan sebagai bahwa sistem pemerintah Negara Kesatuan RI menurut UndangUndang Dasar Negara Republik Indonesia Tahun 1945 menyatakan dan menghormati satuan pemerintahan suatu daerahyang bersifat khusus diatur untuk tujuan Undang-Undang.

Provinsi Aceh menerima Rp56,67 triliun dana otonomi khusus dari pemerintah pusat sejak 20082018. Namun dana tersebut belum mampu mengatasi kemiskinan, yang dimana Jumlah penduduk miskin justru meningkat.

Penelitian yang berkaitan untuk tujuan pemdapatan asli suatu daerahterhadap Kemiskinantelah dilakukan oleh Paulus, dkk (2016), Isramirwati dan Rasuli (2017), Anwar, Palar dan Samual (2016), kemudian penelitian berkaitan untuk tujuan dana alokasi umum terhadap tingkat angka Kemiskinantelah dilakukan oleh Paulus, dkk (2016), Isramirwati dan Rasuli (2017), Anwar, Palar dan Samual (2016), selanjutnya penelitian berkaitan untuk tujuan dana otonomi khusus terhadap tingkat angka Kemiskinantelah dilakukan oleh Anwar, Palar dan Samual (2016).

Perbedaan penelitian ini untuk tujuan penelitian sebelumnya terdapat pada variabel independen yang digunakan dinyatakan sebagai penelitian ini menambahkan variabel dana otonomi khusus. Penelitian sebelumnya menggunakan metode analisis data regresi linier berganda sementara penelitian ini menggunakan analisis regresi data panel.

Penelitian ini bertujuan untuk mengetahui Pengaruh Pemdapatan Asli Daerah, Dana Alokasi Umum dan Dana Otonomi Khusus Terhadap Tingkat angka Kemiskinan. Bagian kedua dari penelitian ini memaparkan kajian teoritis. Pembatasan kajian dalam metode akan di paparkan pada bagian ketiga. Untuk mengetahui hasil dan pembhasan dapat dilihat pada bagian ke empat. Akhirnya kesimpulan dan saran disajikan pada bgian kelima.

\section{KAJIAN TEORITIS \\ Keniskinan}

Cahyat(2004)Kemiskinandinyatakansebag ai ketidakmampuan dalam memperluas pilihan hidup, seperti untuk tujuan dalam menambahkan penilaian yang tidak menunjukkan adanya partisipasi untuk pengambilan suatu kebijakankebijakan pemerintah sebagai indikator kemiskinan. SementaraSen (2005) Kemiskinandinyatakan sebagai bentuk gagalnyafungsi beberapa kapabilitas dasar atau untuk tujuan lainnya seseorang disebutkan miskin jika kekurangan kesempatan untuk mendapatkan kapabilitas ini.

Siregar (2007), Pada dasarnya Pemdapatan Asli Suatu daerah(PAD) Kabupaten/kota yang mempunyai tingkat angka pertumbuhan PAD yang positif mempunyai kemungkinan untuk mempunyai pertumbuhan ekonomi yang lebih 
baik, yang salah satu indikatornya terjadi penurunan kemiskinan, namun apabila suatu daerahtidak mampu menggali penghasilan penghasilan pad disebabkan karena kurangnya keahlian maka berdampak pada peningkatan angka kemiskinan.

Abdullah dan Hallim (2004) menemukan bahwa penghasilan pemdapatan suatu daerahberupa PAD berpengaruh terhadap belanja suatu daerahsecara keseluruhan. Jadi untuk tujuan bertambahnya penghasilan pemdapatan suatu daerahdari PAD akan lebih membantu suatu daerahdalam melaksanakan anggaran yang berpihak pada penduduk miskin (propoor budgeting). Anwar, Palar dan Samual (2016) pemdapatan asli suatu daerahberpengaruh signifikan terhadap penurunan kemiskinan.

Penelitian yang memberi fokus tentang Kemiskinan sudah dilakukan oleh beberapa penelitian diantaranya Paulus, dkk (2016), Isramirwati dan Rasuli (2017), Anwar, Palar dan Samual (2016) untuk tujuan menggunakan analisis data regresi linier berganda.

\section{Pendapatan Asli Suatu daerah}

Pemdapatan Asli Suatu daerahSulistyowati, (2011) menjelaskan bahwa dalam mengelola keuangan, Pemerintah Suatu daerahharus dapat menetapkan asas kemandirian suatu daerahuntuk tujuan menstabilkan penerimaan dari sektor Pemdapatan Asli Suatu daerah(PAD).

\section{Pemdapatan}

Asli

Suatu daerahmenunjukkan penghasilan penerimaan Pemerintah Suatu daerahyang berasal dari suatu daerahitu sendiri yang olah secara individu berdasarkan keahlian yang dimiliki. Mardiasmo, (2002), "pemdapatan asli suatu daerahdinyatakan sebagai penerimaan dari sektor pajak daerah, restribusi suatu daerah, hasil perusahaan milik daerah, hasil pengelolaan kekayaan suatu daerahyang di pisahkan, dan lain-lain".

Halim, (2004) menyebutkan bahwa "pemdapatan asli suatu daerahmenunjukkan semua penerimaan suatu daerahyang berasal dari penghasilan ekonomi asli daerah".

Bastian, (2002) "Penerimaan Pemdapatan Asli Suatu daerahmenunjukkan akumuulasi dari Pos Penerimaan Pajak yang mengisi Pajak Suatu daerahdan Pos Retribusi Daerah, Pos Penerimaan selain Pajak yang berisi sejumlah hasil dari perusahaan milik daerah, Pos Investasi serta Penghasilan Daya Alam.

Penelitian yang memberi fokus tentang Kemiskinansudah dilakukan oleh beberapa penelitian diantaranya Paulus, dkk (2016), Isramirwati dan Rasuli (2017), Anwar, Palar dan
Samual (2016) untuk tujuan menggunakan analisis data regresi linier berganda.

\section{Dana Alokasi Umum}

Dana Alokasi Umum, selanjutnya disebut DAU, dinyatakan sebagai dana perimbangan dan berpenghasilan dari pemdapatan APBN yang dialokasikan untuk tujuan perataan kemampuan keuangan suatu daerahuntuk mendana kebutuhan suatu daerahdalam rangka pelaksanaan Desentralisasi.

Kementrian Keuangan (2018) Dana Alokasi Umum (DAU) menunjukkan salah satu bentuk transfer dana dari pemerintah kepada pemerintah suatu daerahyang berpenghasilan dari pemdapatan Anggaran pemdapatan dan belanja Negara.

Penelitian berkaitan untuk tujuan dana alokasi umum terhadap tingkat angka Keniskinantelah dilakukan oleh Paulus, dkk (2016), Isramirwati dan Rasuli (2017), Anwar, Palar dan Samual (2016) untuk tujuan menggunakan analisis data regresi linier berganda.

\section{Dana Otonomi Khusus}

Penelitian berkaitan untuk tujuan dana alokasi umum terhadap tingkat angka Kemiskinantelah dilakukan oleh Paulus, dkk (2016), Isramirwati dan Rasuli (2017), Anwar, Palar dan Samual (2016) untuk tujuan menggunakan analisis data regresi linier berganda. Dana Otonomi Khusus Berdasarkan Kamus Besar Bahasa Indonesia (2008), otonomi dinyatakan sebagai pola pemerintahan sendiri. Otonomi suatu daerahdinyatakan sebagai hak warga yang tinggal di suatu daerah, mengendalikan dan membangun urusannya sendiri untuk tujuan menghormati peraturan yang berlaku (Haniff Nurcholiss, 2007). Penelitian berkaitan untuk tujuan dana otonomi khusus terhadap tingkat angka Keniskinantelah dilakukan oleh Anwar, Palar dan Samual (2016) untuk tujuan menggunakan analisis data regresi linier berganda. 
Kerangka Konseptual

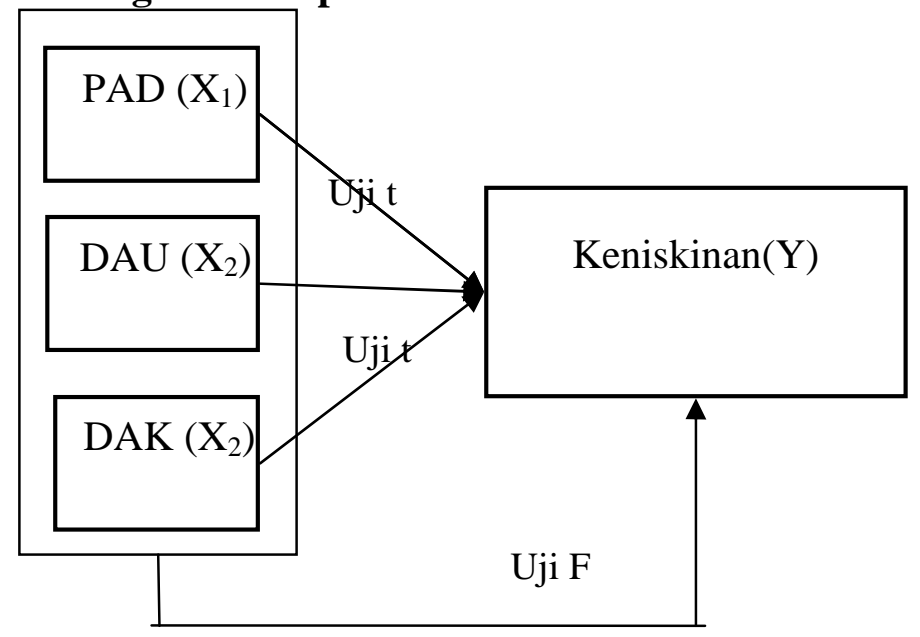

Kerangka konseptual dalam penelitian ini digunakan untuk menjelaskan pengaruh antara variabel indeoenden terhadap variabel dependen baik secara parsial maupun secara simultan. Secara parsial di gunakan untuk melihat apakah pemdapatan asli suatu daerah, dana alokasi umum dan dana otonomi khusus berpengaruh terhadap tingkat angka kemiskinan.

\section{Hipotesis}

$\mathrm{H}_{1}$ :Pemdapatan Asli Suatu daerah berpengaruh terhadap Kemiskinan di Provinsi Aceh Periode 2010 sampai 2017.

$\mathrm{H}_{2}$ :Dana Alokasi Umum berpengaruh terhadap Kemiskinandi Provinsi Aceh Periode 2010 sampai 2017.

$\mathrm{H}_{3}$ :Dana Otonomi Khusus berpengaruh terhadap Kemiskinandi Provinsi Aceh Periode 2010 sampai 2017.

\section{METODE PENELITIAN \\ Data dan Penghasilan Data.}

Jenis data selanjutnya yang akan di digunakan dalam hal ini dinyatakan sebagai data time series diperoleh dari publikasi Badan Pusat Statistik (BPS) Indonesia. Data yang digunakan dalam penelitian ini dari tahun 2010 sampai 2017.

\section{Definisi Operasional Variabel}

1. Pemdapatan Asli Suatu daerah $\left(\mathrm{X}_{1}\right)$

Pemdapatan Asli Suatu daerahmenunjukkan pemdapatan suatu daerahyang mampu di terima oleh provinsi Aceh. PAD di ukur dalam satuan Rupiah.

2. Dana Alokasi Umum (X2)

Dana Alokasi Umum menunjukkan dana yang di alokasikan olehpemerintah pusat kepada daerah. Dana Alokasi Umu di ukur dalam satuan Rupiah.

3. Dana Otonomi Khusus (X3)
Dana alokasi khusus menunjukkan dana yang berpenghasilan dari APBN yang di berikan kepadakabupaten/ Kota Tertentu. Dana otonomi khusus di ukur dalam satuan Rupiah.

4. Keniskinan(Y)

Kemiskinanmenunjukkan keadaan yang menunjukkan kemampuan masyarakat dalam menjalani kehidupannya. Kemiskinandi ukur dalam satuan Persen.

\section{Metode Analisis Data}

Untuk menganalisis data dalam penelitian ini dinyatakan sebagai untuk tujuan menggunakan aplikasi Eviews yaitu:

\section{Analisis Regresi Data Panel}

Metode penelitian yang digunakan dalam penelitian ini, dinyatakan sebagai analisis regresi linier berganda untuk tujuan data panel. Metode tersebut digunakan untuk melihat pengaruh variabel terikat untuk tujuan variabel bebas.

$$
\mathrm{Y}_{\mathrm{it}}=\mathrm{a}+\mathrm{b}_{1} \mathrm{PAD}_{\mathrm{it}}+\mathrm{b}_{2} \mathrm{DAU}_{\mathrm{it}}+\mathrm{b}_{3} \mathrm{DOU}_{\mathrm{it}+} \mathrm{e}
$$

Keterangan :

$$
\begin{array}{ll}
\mathrm{Y} & =\text { Kemiskinan } \\
\mathrm{X}_{1} & =\text { Pemdapatan Asli Daerah } \\
\mathrm{X}_{2} & =\text { Dana Alokasi Umum } \\
\mathrm{X} 3 & =\text { Dana Otonomi Khusus } \\
\mathrm{b} & =\text { Koefisien Regresi } \\
\mathrm{a} & =\text { Constanta } \\
\mathrm{e} & =\text { error term }
\end{array}
$$

\section{Uji Normalitas}

Setiap variabel model regresi harus menunjukkan distribusi normal. Model regresi yang baik dinyatakan sebagai mempunyai distribusi data normal atau mendekati normal.

Salah satu metode yang digunakan untuk menguji normalitas dinyatakan sebagai untuk tujuan uji Jarque-Bera. Pengujian ini dilakukan untuk tujuan program Eviews yang akan menhasilkan nilai probabilitas ( $\mathrm{p}$-value) yang nantinya akan dibandingkan untuk tujuan tingkat angka signifikansi (alpha). Jika nilai probabilitas signifikansinya di atas 0,05 maka berarti nilai residual berdistribusi normal. Namun sebaliknya, jika nilai probabilitas signifikansinya di bawah 0,05 maka berarti nilai residual berdistribusi normal.

Pada program EViews, pengujian normalitas dilakukan untuk tujuan Jarque-Bera test. Uji Jarque-Bera mempunyai nilai chi square untuk tujuan derajat bebas dua.

\section{Uji Asumsi Klasik}

Uji asumsi klasik secara individu (parsial) menganalisis variabel yang telah ditetapkan diatas untuk melihat pengaruh nyata terhadap pelaksanaan program pelatihan untuk tujuan 
meminimalisir tingkat angka kesalahan. Untuk uji asumsi klasik penelitian ini dilakukan untuk tujuan uji autokorelasi.

Jika terjadi korelasi, maka dinyatakan ada problem autokorelasi. Autokorelasi muncul karena observasi yang berurutan sepanjang waktu berkaitan satu sama lainnya. Ada cara yang dapat digunakan untuk mendeteksi ada atau tidaknya autokorelasi. Salah satunya untuk tujuan Serial Correlation LM Test yang untuk tujuan menggunakan nilai Durbin Waston (Ghozali, 2007).

Pengujian autokorelasi untuk tujuan nilai LM Test melalui $O b s^{*} R$-squared dan Prob. ChiSquare(2) yang harus lebih besar dari 0.05 agar disimpulkan tidak terjadi autokorelasi.

\section{Uji Multikolinieritas}

Uji multikolinearitas dinyatakan sebagai salah satu pengujian di dalam asumsi klasik yang berguna untuk melihat apakah variabel-variabel independen di dalam penelitian mempunyai hubungan atau tidak.(Ghozali, 2014) mengatakan bahwa model regresi linear berganda yang baik tidak mempunyai hubungan di antara variabelvariabel bebasnya. Uji multikolinieritas dapat dilihat melalui nilai centered VIF.

\section{Uji Heteroskedastisitas}

Uji heteroskedastisitas bertujuan untuk menguji apakah dalam model regresi terjadi ketidaksamaan variance dari residual satu pengamatan ke pengamatan lain. Iqbal (2012) Keputusan terjadi atau tidaknya heteroskedastisitas pada model regresi linier dinyatakan sebagai untuk tujuan melihat Nilai Prob. F-statistic (F hitung). Apabila nilai Prob. F hitung lebih besar dari tingkat angka alpha $0,05(5 \%)$ maka $\mathrm{H} 0$ diterima yang artinya tidak terjadi heteroskedastisitas, sedangkan apabila nilai Prob.

$\mathrm{F}$ hitung lebih kecil dari dari tingkat angka alpha $0,05(5 \%)$ maka $\mathrm{H} 0$ ditolak yang artinya terjadi heteroskedastisitas.

\section{Pengujian Hipotesis}

\section{Uji t}

Untuk mengetahui pengaruh variabel bebas secara parsial atau individu terhadap variabel tidak bebas untuk tujuan asumsi variabel yang lain konstan. Pengujian ini dilakukan untuk tujuan melihat derajat signifikan masing-masing variabel bebas menggunakan Eviews.

Jika $\mathrm{t}$ hitung $>\mathrm{t}$ tabel maka hipotesis menyatakan menerima $\mathrm{H}_{\mathrm{a}}$ secara parsial untuk tujuan tingkat angka signifikan $<\alpha=0,05$. Dasar pengambilan keputusan:

a. Jika probabilitas (signifikan) $<0,05(\alpha)$ maka $\mathrm{H}_{\mathrm{a}}$ diterima secara parsial. b. Jika probabilitas (signifikan) $>0,05(\alpha)$ maka $\mathrm{H}_{\mathrm{a}}$ ditolak secara parsial.

Pada derajat keyakinan (level significant $)=$ $5 \%$, apabila $\mathrm{t}$ hitung $>\mathrm{t}$ tabel maka variabel bebas berpengaruh secara parsial terhadap variabel terikat. Sebaliknya, apabila $\mathrm{t}$ hitung $<\mathrm{t}$ tabel maka hipotesisditolak, berarti bahwa variabel bebas tidak berpengaruh terhadap variabel terikat.

\section{Uji F}

Uji F Pengujian ini bertujuan untuk mengetahui pengaruh variabel independen secara bersama-sama terhadap variabel dependen untuk tujuan melihat nilai signifikansi F. Bila fhitung > ftabel untuk tujuan tingkat angka signifikan 5\%, maka dapat disimpulkan bahwa secara parsial variabel independen berpengaruh signifikan terhadap variabel dependen. Jika fhitung < ftabel untuk tujuan tingkat angka signifikan 5\%, maka dapat disimpulkan bahwa variabel independen tidak berpengaruh terhadap variabel dependen.(Ghozali, 2006).

\section{Korelasi dan Determinan}

Koefesien korelasi menunjukkan bahwa nilai koefisien korelasi (r) sebesar 0.491. Sugiyono, (2009) jika koefisien korelasi bernilai 0,70 sampai mendekati 1,00 (plus atau minus) menunjukkan derajat hubungan yang tinggi, koefisien korelasi lebih besar dari 0,40 sampai di bawah 0,70 (plus atau minus) menunjukkan derajat hubungan yang sedang, apabila koefisien korelasinya di atas 0,20 sampai 0,40 (plus atau minus) maka menunjukkan derajat hubungan yang rendah.

Analisis ini dipergunakan untuk mengetahui proporsi variabel independen dalam memberikan kontribusinya terhadap variabel dependen dan hasil perhitungan dari analisis ini berupa prosentase. Untuk mengetahui nilai koofisien determinasi dapat diketahui dari nilai adjusted $\mathrm{R}$ square pada tabel model summaryb dalam output Eviews.

Priyanto, (2010), menyebutkan bahwa analisis determinasi digunakan untuk mengetahui prosentase sumbangan pengaruh variabel independen $(X)$ secara serentak terhadap variabel dependen $(\mathrm{Y})$.

\section{HASIL PENELITIAN DAN PEMBAHASAN \\ a. Normalitas}

Ghozali, (2012) Uji normalitas dalam sebuat penelitian di gunakan untuk melakukan sebuah uji atas data yang memiliki distribusi secara normal. Dalam sebuah penelitian yang menggunakan analisis regresi diharapkan memiliki dustribusi data yang normal. Menurut Pakar statistic Widarjono (2013), menyatakan bahwa data 
terdistribusi secara normal dalam penelitian apabila nilai jarqu bera lebih kecil dari chi square dan probabilitas jarqu bera lebih besar dari 0,05.

Penelitian ini menggunakan uji statistic dengan metode jarque bera. Apabila nilai $\mathrm{JB}<$ nilai $\mathrm{X}^{2}$ tabel, maka nilai residual terdistribusi tidak normal dan apabila nilai JB hitung > nilai $\mathrm{X}^{2}$ tabel, maka nilai residual terdistribusi untuk tujuan normal.

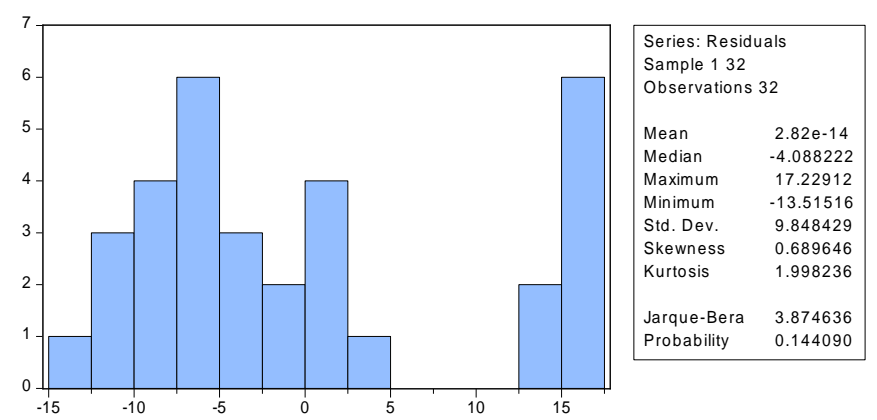

Gambar 2. Normalitas

\section{Sumber : Hasil penelitian, 2019 (Output Eviews} 8)

Dari gambar diatas dapat dilihat bahwa grafik histrogram dapat membentuk pola distribusi simetris, untuk tujuan demikian maka dinyatakan residual terdistribusi normal. Hasil uji normalitas yang dilihat dari perbandingan nilai JB menunjukkan bahwa data terdistribusi normal dimana nila JB $<\mathrm{X}^{2}$ (chi-square) dinyatakan sebagai $3,87<7,81$, (Gujarati, 2012).

Hasil uji normalitas juga dapat di lihat untuk tujuan membandingkan nilai antara probabilitas JB dan nilai signifikan 5\%. Hasil dari uji normalitas menunjukkan bahwa nilai Prob JB > 0,05 dinyatakan sebagai sebesar $0,144>0,05$ maka dapat disimpulkan bahwa residual berdistribusi normal, (Gujarati, 2012).

\section{b. Uji Asumsi Klasik}

\section{Uji Multikolinieritas}

Tabel 3 Uji Multikolinieritas

\begin{tabular}{|c|c|c|c|}
\hline & PAD & DAU & DOK \\
\hline PAD & 1 & 0.23492 & 0.01484 \\
\hline DAU & 0.23492 & 1 & 0.65480 \\
\hline DOK & 0.01484 & 0.65480 & 1 \\
\hline
\end{tabular}

Hasil uji multikolinieritas dapat dilihat berdasarkan uji korelasi. Pada tabel di atas yang menunjukkan bahwa model ini terbebas dari masalah multikolinieritas untuk tujuan melihat hasil output antara variabel dalam regresi tidak terdapat multikolinieritas karena nilai tolerance dibawah 0,9 .

\section{Uji Heteroskedastisitas}

Tabel 4 Uji Heteroskedastisitas

\begin{tabular}{|l|c|c|c|}
\hline \multicolumn{3}{|l|}{ Heteroskedasticity Test: White } & \\
\hline F-statistic & 4.679082 & Prob. F(3,28) & 0.0090 \\
\hline $\begin{array}{l}\text { Obs*R-squared } \\
\begin{array}{l}\text { Scaled explained } \\
\text { SS }\end{array}\end{array}$ & $\begin{array}{c}\text { Prob. Chi- } \\
\text { Square(3) }\end{array}$ & 0.0136 \\
\hline
\end{tabular}

Dari hasi tabel 4 di atas menunjukkan bahwa nilai dilihat dari probabilitas Chi-Squared sebesar 0,252 lebih besar dari nilai signifikansi 5\% sehingga dapat disimpulkan bahwa tidak ada kesalahan penganggu yang muncul antara runtutan pengamatan dalam penelitian ini.

\section{Uji Autokorelasi}

Berdasarkan hasil output eviews menunjukkan bahwa nilai Durbin Watson sebesar 0,360 dan dilai Dl dinyatakan sebagai 0,997 serta nilai du dinyatakan sebagai 1,676 . Karena nilai $\mathrm{dw}>0$ dan $<\mathrm{du}$ dinyatakan sebagai $0,360>0$ dan $0,360<1,676$ ) maka dalam penelitian ini tidak terjadi autokorelasi.

\section{c. Hasil Regresi Data Panel}

Setelah dilakukan analisis maka dapat dilakukan hasil regresi data panel. Hasil estimasi dapat dilihat pada Tabel 5berikut:

Tabel 5.

Regresi Data Panel

Dependent Variable: Y?

\begin{tabular}{|c|c|c|c|c|}
\hline Variable & \multicolumn{2}{|l|}{ Coefficient } & \multicolumn{2}{|c|}{ statistik Prob } \\
\hline \multirow{3}{*}{$\mathrm{C}$} & \multirow{3}{*}{98.57388} & 19.5831 & 5.03359 & 0.000 \\
\hline & & 8 & & 8 \\
\hline & & 0.14139 & 0.71680 & 0.480 \\
\hline \multirow[t]{2}{*}{ LOG(X1?) } & 0.101351 & 2 & & 1 \\
\hline & \multirow[b]{2}{*}{-2.334614} & 0.89956 & & 0.015 \\
\hline \multirow[t]{2}{*}{ LOG(X2?) } & & 9 & 2.595259 & \\
\hline & \multirow{2}{*}{\multicolumn{2}{|c|}{-0.328690}} & - & - $\quad 0.223$ \\
\hline LOG(X3?) & & & 1.2477 & 77 \\
\hline \multicolumn{5}{|l|}{ Fixed Effects (Cross) } \\
\hline $\begin{array}{l}\text { _ACEH_BESAR--C } \\
\text { _ACEH_TAMIANG- }\end{array}$ & \multicolumn{4}{|l|}{16.00210} \\
\hline$-\mathrm{C}$ & \multicolumn{4}{|l|}{-14.44993} \\
\hline _ACEH_UTARA--C & \multicolumn{4}{|l|}{11.62240} \\
\hline _PIDIE_JAYA--C & \multicolumn{4}{|l|}{-13.17457} \\
\hline \multicolumn{5}{|c|}{ Cross-section fixed (dummy variables) } \\
\hline R-squared & 0.996474 & \multicolumn{2}{|c|}{ Mean dependent var } & 4.34969 \\
\hline Adjusted R-squared & 0.995628 & \multicolumn{2}{|c|}{ S.D. dependent var } & 0.57396 \\
\hline S.E. of regression & 1.360358 & \multicolumn{2}{|c|}{ Akaike info criterion } & .644013 \\
\hline Sum squared resid & 46.26436 & \multicolumn{2}{|c|}{ Schwarz criterion } & .964643 \\
\hline Log likelihood & -51.30421 & \multicolumn{2}{|c|}{ Hannan-Quinn criter. } & .750293 \\
\hline F-statistic & 1177.621 & \multirow{2}{*}{\multicolumn{2}{|c|}{ Durbin-Watson stat }} & \multirow[t]{2}{*}{.012757} \\
\hline Prob(F-statistic) & 0.000000 & & & \\
\hline
\end{tabular}

Penghasilan : Data eviews (data diolah)

Berdasarkan tabel 5 diatas, maka persamaan regresi yang dapat disusun di dalam 
penelitian ini dinyatakan sebagai sebagai berikut : $\mathrm{KS}=98.57388+0.101351 \log \mathrm{X}_{1}-2.334614$ $\log X_{2}-0.328690 \log X_{3}$

Berdasarkan persamaan di atas, dapat dijelaskan bahwaKonstanta sebesar 98.57388 artinya variabel PAD, DAU dan DOK dianggap bernilai 0, maka nilai Keniskinantetap sebesar 98.57388. Nilai koefisien regresi PAD sebesar0.101351 menunjukkan hubungan positif (searah) yang memberikan arti bahwa setiap kenaikan PAD sebesar 1\% menyebabkan Keniskinanmeningkat sebesar $0.101351 \%$, untuk tujuan asumsi DAU dan DOK dianggap tetap.

Kemudian koefisien regresi DAU sebesar 2.334614 menunjukkan hubungan negatif (tidak searah) yang memberikan arti bahwa setiap kenaikan DAU sebesar $1 \%$ menyebabkan Keniskinanmenurun sebesar $2.334614 \%$, untuk tujuan asumsi PAD dan DOK dianggap tetap.

Koefisien regresi DOK sebesar -0.328690 menunjukkan hubungan negatif (tidak searah) yang memberikan arti bahwa setiap kenaikan DOK sebesar $1 \%$ menyebabkan Keniskinanmenurun sebesar $-0.328690 \%$, untuk tujuan asumsi PAD dan DAU dianggap tetap.

Nilai koefisien Fixed Effect pada Kabupaten Aceh Besar dinyatakan sebagai 16.00210 dan nila $\mathrm{C}$ dinyatakan sebagai 98.57388, artinya apabila terjadi peningkatan Kemiskinansebesar $1 \%$ maka akan meningkatkan pemdapatan asli daerah, dana alokasi umum dan dana otonomi khusus 16,00\%.

Nilai koefisien Fixed Effect pada Kabupaten Aceh Tamiang dinyatakan sebagai 14,44993 dan nila C dinyatakan sebagai 98.57388, artinya apabila terjadi peningkatan Kemiskinansebesar $1 \%$ maka akan menurunkan pendapatan asli daerah, dana alokasi umum dan dana otonomi khusus $14,44 \%$.

Nilai koefisien Fixed Effect pada Kabupaten Aceh Utara dinyatakan sebagai 11,62240 dan nila $\mathrm{C}$ dinyatakan sebagai 98.57388, artinya apabila terjadi peningkatan Kemiskinansebesar $1 \%$ maka akan meningkatkan pemdapatan asli daerah, dana alokasi umum dan dana otonomi khusus $11,62 \%$.

Nilai koefisien Fixed Effect pada Kabupaten Pidie Jaya dinyatakan sebagai 13,17457 dan nila $\mathrm{C}$ dinyatakan sebagai 98.57388, artinya apabila terjadi peningkatan Kemiskinansebesar $1 \%$ maka akan menurunkan pemdapatan asli daerah, dana alokasi umum dan dana otonomi khusus $13,17 \%$.

Pengujian Hipotesis

Hasil Uji t
Adapun hasil pengujian hipotesis di dalam penelitian ini dinyatakan sebagai sebagai berikut:

1. Secara parsialPemdapatan asli suatu daerahtidakberpengaruh terhadap Kemiskinanpada pemerintah Provinsi Aceh. Hal ini ditunjukkan oleh hasil nilai $\mathrm{t}_{\text {hitung }}<\mathrm{t}$ tabel yakni $0,716<1,701$ dan nilai signifikan sebesar $0.480>0.05$. Untuk tujuan demikian penelitian ini menolak $\mathrm{H}_{1}$.

2. Secara parsiaDana Alokasi Umumberpengaruh negatif dan signifikan terhadap Kemiskinanpada pemerintah Provinsi Aceh. Hal ini ditunjukkan oleh hasil nilai $t$ hitung $>t$ tabel yakni 2,595 $>1,701$ dan nilai signifikan sebesar $0.015<$ 0.05 . Untuk tujuan demikian penelitian ini menerima $\mathrm{H}_{2}$.

3. Secara parsiaDana Otonomi Khusustidakberpengaruh terhadap Kemiskinanpada pemerintah Provinsi Aceh. Hal ini ditunjukkan oleh hasil nilai $\mathrm{t}_{\text {hitung }}<\mathrm{t}$ tabel yakni 1,247<1,701dan nilai signifikan sebesar $0.223>0.05$. Untuk tujuan demikian penelitian ini menolak $\mathrm{H}_{3}$

\section{Hasil uji F}

Adapun hasil pengujian hipotesis di dalam penelitian ini dinyatakan sebagai sebagai berikut:

1. Untuk tujuan ketentuan apabila nilai $F_{\text {hitung }}>$ dari $\mathrm{F}_{\text {tabel }}$ maka $\mathrm{H}_{4}$ diterima, jika $\mathrm{F}_{\text {hitung }}<$ $\mathrm{F}_{\text {tabel }}$ maka $\mathrm{H}_{4}$ ditolak. Artinya apabila $\mathrm{F}_{\text {hitung }}$ $>$ dari $F_{\text {tabel }}$ maka terdapat pengaruh PAD, DAU dan DOK terhadap Kemiskinan. Secara simultan PAD, DAU dan DOK berpengaruh terhadap Kemiskinandimana $\mathrm{F}_{\text {hitung }}>\mathrm{F}_{\text {tabel }}$ dinyatakan sebagai 1177,621 $>3,008$ dan nilai signifikan sebesar $0.000<$ 0.05 . adanya pengaruh positif menunjukkan bahwa peningkatan pemdapatan asli daerah, dana alokasi umum dan dana otonomi khusus akan menyebabkan peningkatan angka kemiskinan.

\section{d. Koefisien Korelasi dan Determinasi}

Hasil uji Koefisen determinasi $\mathrm{R}^{2}$ untuk tujuan regresi data panel, maka yang di lihat dari Ajudted R Square dinyatakan sebagai sebesar 0,7464 atau $0,9956 \%$. Hasil ini berarti PAD, DAU dan DOK berpengaruh terhadap Keniskinansebesar 99,56\%. Sedangkan sisanya $0,44 \%$ di pengaruhi oleh faktor-faktor lain di luar model. Koefisien determinasi $\left(\mathrm{R}^{2}\right)$ dinyatakan sebagai sebesar 0,9956, maka koefisien korelasi (R) dinyatakan sebagai sebesar $\sqrt{R^{2}}=$ dinyatakan sebagai 0,8639. Hasil ini 
berhubungan kuat secara positif, karena nilai $\mathrm{R}$ mendekati positif $(+1)$.

\section{Pembahasan}

\section{Pengaruh Pendapatan Asli Suatu daerah terhadap Kemiskinan}

Hasil dari penelitian ini menunjukkan bahwa Pendapatan asli suatu daerahtidak berpengaruh terhadap Kemiskinanpada pemerintah Provinsi Aceh. Hal ini ditunjukkan oleh hasil nilai $\mathrm{t}$ hitung $<\mathrm{t}$ tabel yakni $0,716<1,701$ dan nilai signifikan sebesar $0.480>0.05$.

Pada dasarnyaPendapatan Asli Suatu daerah(PAD) Kabupaten/kota yang mempunyai tingkat angka pertumbuhan PAD yang positif mempunyai kemungkinan untuk mempunyai pertumbuhan ekonomi yang lebih baik, yang salah satu indikatornya terjadi penurunan kemiskinan, namun apabila suatu daerahtidak mampu menggali penghasilan penghasilan pad disebabkan karena kurangnya pengetahuan dan keahlian maka akan berdampak pada peningkatan angka kemiskinan.

Sesuai untuk tujuan hasil penelitian Siregar (2007) bahwa Paulus (2016), Isramirwati dan Rasuli (2017) dan Anwar, Palar dan Samual (2016) pemdapatan asli suatu daerahberpengaruh signifikan terhadap penurunan kemiskinan. PAD menunjukkan salah satu penghasilan belanja daerah, Abdullah dan Halim (2004) menemukan bahwa penghasilan pemdapatan suatu daerahberupa PAD berpengaruh terhadap belanja suatu daerahsecara keseluruhan. Jadi untuk tujuan bertambahnya penghasilan pendapatan suatu daerahdari PAD akan lebih membantu suatu daerahdalam melaksanakan anggaran yang berpihak pada penduduk miskin (propoor budgeting).

\section{Pengaruh Dana Alokasi Umum terhadap Kemiskinan}

Hasil dari penelitian ini menunjukkan bahwa dana alokasi umum berpengaruh negatif dan signifikan terhadap Kemiskinan pada pemerintah Provinsi Aceh. Hal ini ditunjukkan oleh hasil nilai $\mathrm{t}$ hitung $>\mathrm{t}$ tabel yakni 2,595 >1,701dan nilai signifikan sebesar $0.015<0.05$. Dalam rangka untuk menekan tingkat angka Kemiskinan pemerintah juga memberikan dana alokasi umum.

Adanya pengaruh negatif menunjukkan bahwa semakin besar penerimaan dana alokasi umum maka akan mengurangi tingkat angka kemiskinan. Dana Alokasi umum menunjukkan sejumlah dana yang dialokasikan Pemerintah Pusat kepada setiap Suatu daerahOtonom setiap tahunnya sebagai dana pembangunan.

Hasil penelitian ini sejalan untuk tujuan penelitian yang dilakukan oleh Paulus (2016) yang menyatakan bahwa dana alokasi umum berpengaruh terhadap tingkat angka kemiskinan. Hal ini menunjukkan bahwa peningkatan akan dana alokasi umum akan mengurangi angka kemiskinan. Hasil penelitian Isramirwati dan Rasuli (2017) juga membuktikan bahwa dana alokasi umum mampu mengurangi jumlah Kemiskinandalam suatu daerah.

\section{Pengaruh Dana Otonomi Khusus terhadap Kemiskinan}

Hasil dari penelitian ini menunjukkan bahwa Dana Otonomi Khusus tidak berpengaruh terhadap Kemiskinanpada pemerintah Provinsi Aceh. Hal ini ditunjukkan oleh hasil nilai $\mathrm{t}_{\text {hitung }}<\mathrm{t}$ tabel yakni $1,247<1,701$ dan nilai signifikan sebesar $0.223>$ 0.05 .

Pada dasarnya pemerintah sudah mengupayakan untuk mengurangi tingkat angka Kemiskinandinyatakan sebagai untuk tujuan memberikan otonomi khusus untuk Aceh juga mengalokasikan dana otonomi khusus. Tidak adanya pengaruh antara pemberian dana otonomi khusus dikarenakan penyaluran dan penggunaaan dari dana tersebut belum tepat sasaran.

\section{KESIMPULAN DAN SARAN}

Berdasarkan hasil penelitian dan pembahasan, maka peneliti mengemukakan kesimpulan sebagai berikut :

1. PAD belum memberikan dampak terhadap pengentasan Keniskinan di Provinsi Aceh

2. DAU telah memberikan dampak terhadap pengentasan Keniskinan di Provinsi Aceh

3. DOK belum memberikan dampak terhadap pengentasan Keniskinan di Provinsi Aceh

\section{DAFTAR PUSTAKA}

Adi dan Pujawan (2011). Dampak Desentralisasi Fiskal Terhadap Pertumbuhan Ekonomi. Jurnal Kritis. Universitas Kristen Satya Wacana. Salatiga.

Bastian (2006). Akuntansi Sektor Publik. Salemba Empat. Jakarta

Boediono, (2001). Ekonomi Makro Edisi 4. Yokyakarta: BPFE.

Darise, Nurlan. (2008). Akuntansi Keuangan Suatu daerah(Akuntansi Sektor Publik). Jakarta: Penerbit Indeks.

Erlina, Sri Mulyani, (2007). Metodelogi Penelitian Bisnis : Untuk Akuntansi Dan Manajemen, Cetakan Pertama,USU Press, Medan. hal-4 
Ghozali, Imam. (2009). Aplikasi Analisis Multivariate Untuk tujuan Program SPSS.

Semarang Penerbit Universitas Diponegoro.

Halim A.(2001). Manajemen Keuangan Publik. Yogyakarta: UPP AMP.YKPN

Hartanto (2010) Perencanaan Pajak Edisi Pertama, BPFE-Yogyakarta.

Indriantoro, dan Supomo, (2002). Metedologi Penelitian Bisnis. Yogyakarta : Edisi Pertama

Iqbal, Muhammad (2014), Pengolahan data Regresi Linier Berganda untuk tujuan Eviesw

Megawati dan Soetojo (2016) Kontribusi Retribusi Pasar Terhadap Pemdapatan Asli Suatu daerah(Pad) Kabupaten Sidoarjo.

Mardiasmo. (2002). Otonomi dan Manajemen Keuangan Daerah. Penerbit ANDI.Yogyakarta.

Republik, Indonesia. (2004) Undang-Undang Nomor 32 Tahun 2004 tentang Pemerintah Daerah

Republik, Indonesia. (2006). Undang-undang Nomor 11 Tentang Pemerinthan Aceh

Republik, Indonesia. (2009). Undang-Undang Nomor 28 tentang Ketentuan umum dan tata cara perpajakan

Rencana Kerja Pemerintah Kota Lhokseumawe, tahun 2014

Riyanto (2001) Dasar-dasar Pembelanjaan Perusahaan. BPFE, Yogyakarta

Saragih JP.(2002). Desentralisasi Fiskal dan Keuangan Suatu daerahdalam Otonomi. Jakarta: Ghalia Indonesia. hal- 40

Saepurrahman (2015), Pengaruh Pajak Hotel Dan Pajak Restoran Terhadap Pemdapatan Asli Derah (Studi Kasus Pada Dinas Pemdapatan Kota Tasikmalaya)

Setiawan Ardy (2015). Efektivitas Pemungutan Pajak Suatu daerahDan Retribusi Suatu daerahDalam Meningkatkan Pemdapatan Asli Daerah. Universitas Siliwangi
Sutrisno (2010) Manajemen Penghasilan Daya Manusia. Edisi Pertama. Cetakan. Pertama

Sulistiyowati (2011), Keuangan Pemerintah Daerah, Prenada Media Group:Jakarta. 